\title{
Our Friend in the North: The Origins, Evolution and Appeal of the Cult of St Duthac of Tain in the Later Middle Ages
}

ABSTRACT

St Duthac of Tain was one of the most popular Scottish saints of the later middle ages. From the late fourteenth century until the reformation devotion to Duthac outstripped that of Andrew, Columba, Margaret and Mungo, and Duthac's shrine in Easter Ross became a regular haunt of James IV (1488-1513) and James V (1513-42). Hitherto historians have tacitly accepted the view of David McRoberts that Duthac was one of several local saints whose emergence and popularity in the fifteenth century was part of a wider self-consciously nationalist trend in Scottish religious practice. This study looks beyond the paradigm of nationalism to trace and explain the popularity of St Duthac from the shadowy origins of the cult to its heyday in the early sixteenth century.

In July 1560 Nicholas Ross, the custodian of the shrine of St Duthac, situated in the small town of Tain in Easter Ross, made preparations to travel south to Edinburgh to attend the Scottish parliament. ${ }^{1}$ Mindful of the damage wrought since 1559 by iconoclastic crowds further south, Nicholas left the silver and gold relics belonging to the shrine in the safekeeping of his kinsman, Alexander Ross of Balnagown. ${ }^{2}$ They would never be seen again. The reformation brought an abrupt end to the official cult of St Duthac, although for the next century exiled catholics, such as John Leslie, bishop of Ross (1565-96), continued to reminisce about the days when 'Kingis, Princis and the commune people' flocked

1 Thomas Thomson and Cosmo Innes (eds), Acts of the Parliaments of Scotland, 11 vols (Edinburgh, 1814-75), [APS], iii. 25. Ross was the provost of the collegiate church of Tain (1549-67) and voted in favour of the reformed Confession of the Faith. There were several different spellings of the name of the saint of Tain. For simplicity I will use Duthac, unless quoting directly from a primary source.

${ }^{2}$ William Macgill (ed.), Old Ross-shire and Scotland: As seen in the Tain and Balnagown documents, 2 vols (Inverness, 1909-11), i. 8. The relics included the saint's head encased in silver, his breastbone in a gold container and a portable shrine which was made of silver with gold gilding. Their combined value was $£ 113$.

TOM TURPIE is a Teaching Assistant at the University of Stirling. 
to the tomb of the northern saint. ${ }^{3}$ The most frequent visitor amongst these kings was James IV, whose annual pilgrimages to Tain, from 1493 until his death at Flodden, are the context in which the saint and his shrine are best known to scholars of late medieval Scotland. ${ }^{4}$ Although to modern Scots the saint of Tain is less familiar than Andrew, Columba, Margaret, Mungo and perhaps Ninian, from the late fourteenth century until the reformation recorded devotion to Duthac outstripped that of many of these more familiar saints. ${ }^{5}$ Indeed, in the later middle ages Duthac was one of only a handful of Scottish saints with a cult of national significance. Dedications to him stretched from the English border to the northern isles. ${ }^{6}$ Yet, despite Duthac's broad popularity, studies of the later middle ages have tended to focus on the cosmopolitan trends of Marian and Passion devotion and the emergence of new international cults in the kingdom. ${ }^{7}$ Duthac, by contrast, has featured only fleetingly in modern scholarship. ${ }^{8}$

3 The quotation is from Leslie's 1578 description of pilgrimage to Tain, featured in his history of Scotland. Duthac is also mentioned in a work of 1631 by David Chambers, discussed below (E.G. Cody and William Muriston (eds), Historie of Scotland Wrytten First in Latin by Jhone Leslie and Translated in Scottish by James Dalrymple, 2 vols (Edinburgh, 1888), i. 335); David Chambers, De Scotorum fortitudine, doctrina, and pietate, ac de ortu and progressu haeresis in regnis Scotiae and Angliae (Paris, 1631), 112-3.

4 Peter Yeoman, Pilgrimage in Medieval Scotland (London, 1999), 106-9 specifically only includes Duthac and Tain in a section on the pilgrimages of James IV. For a brief synopsis of James's pilgrimages, see Norman Macdougall, James IV (Edinburgh, 1989), 196-8.

${ }^{5}$ Clancy suggests that most Scots would consider these saints to be the traditional saintly founders of Scotland (T.O. Clancy, 'Scottish saints and national identities in the early middle ages', in Alan Thacker and Richard Sharpe (eds), Local Saints and Local Churches in the Early Medieval West (Oxford 2002), 397-420, at 397); my own informal questioning of non-academics supports this supposition. In the Northern Isles the local saints Magnus and Rognvald also have a high profile as part of the distinct identity of the two island groups.

6 See Table 1 below for recorded dedications to Duthac in this period.

${ }^{7}$ For a discussion of recent trends in this field, see David Ditchburn, 'The "McRoberts thesis" and patterns of sanctity in late medieval Scotland', in Steve Boardman and Eila Williamson (eds), The Cult of Saints and the Virgin Mary in Medieval Scotland (Woodbridge, 2010), 177-94. Notable exceptions to the focus on international saints in the later middle ages are Simon Taylor, 'The cult of St Fillan in Scotland', in T.R. Liszka and Lorna Walker (eds) The North Sea World in the Middle Ages: Studies in the cultural history of north-western Europe (Dublin, 2001), 175-211; Helen Brown, 'Saint Triduana of Restalrig? Locating a saint and her cult in late medieval Lothian and beyond', in Debra Strickland (ed.), Images of Medieval Sanctity: Essays in Honour of Gary Dickson (Leiden, 2007), 45-69.

8 John Durkan, 'The sanctuary and college of Tain', Innes Review [IR] 13 (1962) 147-54. The most thorough local history is R.W. Munro and Jean Munro, Tain through the Centuries (Edinburgh, 2005). See too H.G. Slade, The Collegiate Kirk of St Duthac of Tain and The Abbey of Fearn (Tain, 2000); G.A. Brequet, 'The early history of Tain', Transactions of the Inverness Scientific Society and Field Club 6 (1899-1906) 26-44; Cosmo Innes, 'The croziary of St Duthac', Proceedings of the Society of Antiquaries of Scotland [PSAS] 2 (1859) 15. The burgh survey includes a brief explanation of the late medieval cult: Alison Cathcart, R.D. Oram, P.F. Martin and C.E McKean (eds), Historic Tain: Archaeology and Development (Edinburgh, 2009), appendix 1. A statue of Duthac is prominently displayed in the medieval religion section of the National Museum of Scotland, Edinburgh. See too D.A. McKay, 'The four heid pilgrimages of Scotland', 
The neglect of national saints, those considered by contemporaries to have been active in Scotland or to have had a hagiographical connection to the kingdom, is partly explained by what Helen Brown described as the seemingly 'barren saintly landscape' of the late medieval kingdom. ${ }^{9}$ Between the canonisation of Queen Margaret (d. 1093) in 1250 and the reformation in 1560 no Scottish saints received formal papal recognition, despite two abortive processes surrounding Duthac in 1418 and Margaret of Denmark in $1487 .{ }^{10}$ The lack of new saints is perhaps not surprising. In the same period only three Englishmen were recognised by the papacy as the canonisation process became increasingly complex, expensive and regionally biased. ${ }^{11}$ However, late medieval Scotland was also conspicuously lacking in 'would be saints', those unofficial cults based upon contemporary figures that failed to receive, or flourished without, papal sanction. ${ }^{12}$ Evidence for aspirant Scottish cults is limited to reported miracles around the tomb of the murdered duke of Rothesay (d. 1402) at Lindores Abbey in Fife. ${ }^{13}$ Since most historical research on later medieval saints focuses on saints who

${ }^{8}$ (Continued) IR 20 (1974) 76-7; I.B. Cowan, 'Church and society', in J.M. Brown (ed.) Scottish Society in the Fifteenth Century (London, 1977), 112-35 at 113; David Ditchburn, Scotland and Europe: The medieval kingdom and its contacts with Christendom, 1214-1560 (East Linton, 2001), 52; David Ditchburn, 'Saints at the door don't make miracles'? The contrasting fortunes of Scottish pilgrimage, c. 1450-1550', in Julian Goodare and A.A. MacDonald (eds), Sixteenth-Century Scotland: Essays in honour of Michael Lynch (Leiden, 2008), 69-98, at 95-6; Richard Fawcett, 'The architectural framework for the cult of saints: some Scottish examples', in Strickland (ed.), Images, 71-94, at 74; Yeoman, Pilgrimage, 106-9.

${ }^{9}$ Brown, 'Triduana', 46-7. Andrew qualifies as a 'Scottish saint' through the presence of his relics in Scotland. Variants of the phrase 'Scottis Sanctis', which appears in the patent issued in 1507 to Scotland's first printers, Walter Chepman and Andrew Millar, can be found in literature from medieval Scotland (Matthew Livingstone $e t$ al. (eds), Registrum Secreti Sigilli Regum Scotorum, 8 vols (Edinburgh, 1908-82), [RSS], i. no. 1546). The definition of the term recorded above follows Alexander Boyle, 'Some saints lives in the breviary of Aberdeen', Analecta Bollandia, 94 (1976) 95-106, at $95-6$.

10 The attempt to have Duthac formally canonised is discussed below. In 1487 William Scheves, archbishop of St Andrews, and the bishops of Glasgow and Aberdeen received a papal letter from Innocent VIII (1484-92) asking for a report on the 'life, character, death and miracles of Margaret, sometime Queen of Scotland' (W.H. Bliss et al. (eds), Calendar of Entries in the Papal Registers Relating to Great Britain and Ireland; Papal Letters, 20 vols (London, etc., 1893-), xiv. 4). There is no evidence that James IV continued this process and nothing further was heard of it. See Norman Macdougall, James III (Edinburgh, 2009), 306.

11 These were Thomas Cantilupe of Hereford (1320), John of Bridlington (1401) and Osmund of Salisbury (1456). For the trends in the canonisation of new saints in the later middle ages, see R.N. Swanson, Religion and Devotion in Europe, c. 1215-c. 1515 (Cambridge, 1995), 148-50.

12 This group was very common in England during this period. For a description of various new, official and unofficial cults, see R.N. Swanson, Church and Society in Late Medieval England (Oxford, 1989), 287-90.

13 Steve Boardman, 'A saintly sinner? The martyrdom of David, duke of Rothesay', in Boardman and Williamson (eds), Cult of Saints, 87-104. For the many failed campaigns based around what Swanson described as 'would be saints' in England, see Swanson, Church and Society, 287-90. 
lived and died in the later middle ages, late medieval Scotland appears to offer meagre resources. ${ }^{14}$

A further reason for this neglect of national saints in the later middle ages is paradoxically the pervasive influence of the most significant work on the topic. David McRoberts argued that the fifteenth century saw a self-consciously nationalist trend in Scottish religious practice, fostered by both the church and the Stewart dynasty, and most apparent in the rediscovery of Scotland's early saints. ${ }^{15}$ Those who have commented on the cults of Ninian, Columba, Kentigern and Duthac in the later middle ages have tended to accept McRobert's view that church-led devotional nationalism and monarchical patronage were the key catalysts for change in the period. ${ }^{16}$ As Ditchburn has pointed out in a recent critique of what he termed the 'McRoberts thesis', while the 'rougher edges' of this argument have been subject to revision, recent scholarship has tended to avoid challenging this central premise, choosing instead to explore international and cosmopolitan devotional practices. ${ }^{17}$

This article examines the attempt to have Duthac canonised in 1418 and his subsequent popularity, which are central to the devotional nationalism thesis. The aim of the study is to look beyond the paradigms of nationalism and royal patronage to explain Duthac's popularity from the shadowy origins of the cult to the halcyon days of royal pilgrimage in the reigns of James IV and James V. In common with other saints, most notably Ninian and Triduana, there are difficulties in identifying the provenance of the historical figure behind the Duthac cult. ${ }^{18}$ Expanded discussion of the saint and his miracles is found only in the early sixteenth-century Aberdeen Breviary which contains nine lessons dedicated to the saint. ${ }^{19}$ They begin by describing a

${ }^{14}$ See Katherine Lewis, 'History, historiography and re-writing the past', in Sarah Salih (ed.), A Companion to Middle English Hagiography (Woodbridge, 2006), 122-40, at 124.

15 David McRoberts, 'The Scottish church and nationalism in the fifteenth century', IR 9 (1968) 3-14, especially 4-8. McRoberts was supported most notably by Leslie Macfarlane, who saw this controlled movement culminating in the attempt to establish a Scottish liturgical use through the Aberdeen Breviary project (1507-10): L.J. Macfarlane, William Elphinstone and the Kingdom of Scotland, 1431-1514: The struggle for order (Aberdeen, 1995), esp. 234.

16 Clancy, 'Scottish saints', 397, 420; Simon Taylor, 'Columba east of Drumalban: some aspects of the cult of Columba in eastern Scotland', IR 51 (2000) 109-28, at 117-20; James Galbraith, 'The middle ages', in Duncan Forrester and Douglas Murray (eds), Studies in the History of Worship in Scotland (Edinburgh, 1996), 19-37, at 23; A.D.M. Barrell, Medieval Scotland (Cambridge, 2000), 252, 267.

17 Ditchburn questions the wider significance of these Scottish saints in late medieval devotional practices, the role of nationalism as a catalyst for the changes and what he describes as McRobert's 'rigid dichotomy between international and national saints' (Ditchburn, 'The "McRoberts thesis"', especially 192-4).

18 For a synopsis of the historiography relating to St Ninian, see Dauvit Broun, 'The literary record of St Nynia: fact and fiction?’, IR 42 (1991) 143-50; G.W.S. Barrow, Saint Ninian and Pictomania (Whithorn 2004), 1-4. For Triduana, see Brown, 'Saint Triduana', 45-69.

19 Breviarium Aberdonense, 2 vols, Bannatyne, Maitland and Spalding Clubs (Edinburgh, 1854), ii. fos. 65-6. 
man of noble birth from northern Scotland who displayed signs of sanctity as a child, when he performed his first miracle by carrying hot coals without suffering burns. ${ }^{20}$ Duthac was then educated in Ireland, specialising in Old and New Testament church law, before returning to northern Scotland where his reputation for kindness and generosity led to ordination as the local bishop. For the remainder of his career Duthac is depicted as a benevolent holy man in the area of the Dornoch firth, performing three further miracles during his lifetime. In the first of these, a man was struck down with a headache. In order to alleviate his pain he sent one of Duthac's disciples to the saint with a gold ring and some meat. Because of the young cleric's negligence, a kite stole the gifts. Duthac forgave the worried young man and summoned the bird, allowing it to keep the food and returning the ring to its owner. The second miracle occurred during a famine. The saint attended a feast at which a special cake was served. The saint miraculously enlarged the cake, so that it could feed the whole community, while its crumbs were bestowed with healing properties. In the third miracle the saint caused the spit, on which a canon from Dornoch was carrying a gift of meat to Duthac, to light the way through dangerous terrain, leading the young man to safety on a dark and stormy night. The final two lessons conclude with Duthac's death on 8 March and the confirmation of his sanctity, following an exhumation of his remains seven years later and the discovery of his uncorrupted body.

While the entry in the Aberdeen Breviary places the saint in a distinct geographical context, delineating his area of cultural influence as the area around Tain, it shows a notable vagueness in locating Duthac within a historical timeframe. The Annals of Ulster appear to solve this problem, including an obit in 1065 which recorded that 'Dubthach the Scot, the chief confessor of Ireland and of Scotland, reposed in Armagh'. ${ }^{21}$ The similarity of the name and the correspondence of the Irish connection with the legends recorded in the Aberdeen Breviary, have led to the identification of this holy man with the man whose cult developed in the later middle ages. ${ }^{22}$ However, although Farmer accepts this premise, Durkan and Ditchburn have placed the death of the saint

${ }^{20}$ Miracles such as this were a common motif used to demonstrate a saint's precocity as a child: E.R. Henken, The Welsh Saints: A study in patterned lives (Woodbridge, 1991), 65.

21 The reference to Dubthach Albanach can be found in S. Mac Airt and G Mac Niocall (eds), Annals of Ulster: Text and translation, Part 1 (Dublin, 1983) [AU], 503, and A.O Anderson (ed.) Early Sources of Scottish History, 2 vols (Edinburgh, 1922) [ES], ii. 10.

${ }^{22}$ See D.H. Farmer, The Oxford Dictionary of Saints (2 ${ }^{\text {nd }}$ edn, Oxford, 1987), 124; Herbert Thurston and Donald Attwater (eds), Butler's Lives of the Saints, 4 vols (London, 1953-4), ii. 526; Alexander Boyle, 'Notes on Scottish saints', IR 32 (1981) 59-83, at 66-7. Watson and Mackinley link the cult to Dubthach Albanach (W.J. Watson, A History of Celtic Place Names in Scotland (Edinburgh, 1926) [CPNS], 283-4; J.M. Mackinley, Ancient Church Dedications in Scotland: Non-scriptural dedications (Edinburgh, 1914), 223). The section in the burgh survey, not linked to a specific date, describes Duthac as a 'synthetic saint' (Cathcart et al., (eds), Historic Tain, 132). 
at $c .1165$ and the Bollandists prefer $c .1250 .{ }^{23}$ These differences are not surprising. Hector Boece, writing in the 1520s, initially placed Duthac's career in the late twelfth and early thirteenth centuries. In Bellenden's translation of Boece's work, the saint is described as the 'preceptoure to sanct Gilbert', a bishop of Caithness who died in 1245; but Boece also noted that 'utheris sayis he wes lang yeris afoir bis tyme', indicating that an alternative account of Duthac's origins was also in circulation by the early sixteenth century. ${ }^{24}$

One tradition, which seems to have stemmed from the area close to the shrine, draws a connection between the life of the saint and the establishment of Tain as a royal burgh. It places Duthac firmly in the eleventh century. This relationship between town and saint was visualised on the burgh seal and noted in an inquest held in $1439 .{ }^{25}$ The desire of Tain's urban hierarchy to display Duthac on its seal was an illustration of the perceived patronal relationship between the saint and town and of Duthac's role as guarantor of the burgh's rights and privileges. This function was outlined more explicitly in the text of the inquest, which took place in response to the destruction of town records during a fire in 1427. ${ }^{26}$ The inquest was presided over by Alexander MacDonald (d. 1449), earl of Ross, and attended by representatives from the Ross of Balnagown and Munro of Foulis families and, perhaps, burgesses of the town. ${ }^{27}$ It established that those dwelling within the sanctuary, centred on the church of Tain and designated by four crosses, were exempt from both royal and comital customs as a result of an immunity granted by Malcolm III (1058-93) in the mid-eleventh century during, or shortly after, the saint's lifetime. ${ }^{28}$

${ }^{23}$ Farmer, Dictionary, 124. The date of 1065 is accepted in Attwater and Thurston (eds), Butler's Lives of the Saints, ii. 526, and in Boyle, 'Notes on Scottish saints', 66-7. The Durkan and Ditchburn date is connected to the second origin legend, to be discussed below (Durkan, 'Sanctuary', 147; Ditchburn, Scotland and Europe, 52). The date in Joannes Bollande (ed.), Acta Sanctorum: Martii (Paris/Rome, 1865), 798-9 seems to be based upon the description of the saint by Chambers from 1631.

${ }^{24}$ E.C. Batho and R.W. Chambers (eds), Chronicles of Scotland Compiled by Hector Boece, Translated into Scots by John Bellenden, 1531, 2 vols (Edinburgh, 1938-41), [Chron. Boece], ii. 229.

25 The seal is featured in R.M. Urquhart, Scottish Burgh and County Heraldry (London, 1973), 61-2 and J.H. Stevenson and Marguerite Wood (eds), Scottish Heraldic Seals, 3 vols (Glasgow, 1940), i. 81. These are undated; a seal from a charter dated 4 Feb. 1534 is displayed in Tain and District Museum.

${ }^{26}$ This inquest is recorded in a sixteenth-century copy, published in Macgill (ed.), Tain, 369. It was mentioned in the confirmation of the town charter in 1587-8 (J.M. Thomson (ed.), Registrum Magni Sigilli Regum Scotorum, 11 vols (Edinburgh, 1882-1914) [RMS], v. no. 1432).

27 The inquest was witnessed by some of the men of the Lord of the Isles, the town baillie Alexander MacCulloch, and local noblemen Alexander and John de Sutherland, Hugh Ross of Balnagown and George Munro of Foulis. Others (John de Spens, John Monylaw and John Bayne) were not connected with these groups and were possibly burgesses. Thomas Monylaw was provost of the collegiate church in 1482.

28 The inquest also stated that immunity had been confirmed by Robert I, David II and Robert II although there is no extant evidence of this. 
The inquest was also attended by the sheriff, William Leslie, and an Inverness burgess, Ferchard Reid, and it is in the context of relations between the northern burghs that the origin legend should be viewed. Although Tain paid stent in 1535 and was represented in parliament from 1567 and in the convention of the royal burghs, it did not obtain official burghal status until 1588. ${ }^{29}$ The privileges then granted included the right to hold various markets, in particular that of $\mathrm{St}$ Duthac on 8 March, and to control communal land and fisheries. ${ }^{30}$ It was presumably these privileges that the Inverness representatives had come to contest in 1439, apparently unsuccessfully. The continuing sensitivity of the Inverness commercial community was shown in 1457 and 1458, when James II (1437-60) and the new earl of Ross, John MacDonald (d. 1503), while making grants to Tain, confirmed the rights of the burghers of Inverness. ${ }^{31}$ These disagreements rumbled on into the late sixteenth century, when Inverness representatives at the convention of royal burghs objected to Tain's enrolment as a free burgh in 1581,1583 and $1584 .^{32}$ While Tain appears, on the strength of the sanctuary, to have gradually evolved the commercial rights associated with a royal burgh, the economic status of the town remained contested, as was regularly highlighted by Inverness burgesses until 1588 .

The legend of Malcolm's grant to the saintly burgh, which corresponds chronologically with the death of Dubthach Albanach in Armagh, has been incorporated into the local narrative of Tain's development. Local tradition explains the contradiction between the presence of the saint's relics in the town and the statement in the Annals of Ulster that Duthac died in Armagh by suggesting that his relics were translated to Easter Ross in $1253 .{ }^{33}$ This legend must be viewed with caution, as it perhaps was by the compilers of the Aberdeen Breviary, who stopped short of placing Duthac in a historical framework. ${ }^{34}$ Tain used the legend in its arguments with Inverness and other local trading centres and nowadays the story provides Tain with a distinctive origin myth; but the lack of corroboration for a translation in 1253 requires us to treat the mid-eleventh century as a possible, rather than probable, source of the cult.

${ }^{29}$ G.S. Pryde, The Burghs of Scotland (Glasgow, 1965), 24-5. Stent payments are recorded in J.D. Marwick (ed.), Records of the Conventions of the Royal Burghs of Scotland ... 1295-1597, 8 vols, Scottish Burgh Rec. Soc. (Edinburgh, 1866-1880), i. 514. Tain paid $£ 1617 s 6 d$, around half of that paid by Elgin (£33 15s) and less than a third of Inverness $(£ 565 s)$.

${ }^{30} R M S$, v. no. 1432 .

${ }^{31}$ Macgill (ed.), Tain, 207. Jean Munro and R.W. Munro (eds), Acts of the Lords of the Isles, 1336-1493 (Edinburgh, 1986), 101.

32 Marwick (ed.), Records, i. 115-6, 163-4, 190. The representatives of Tain, when called upon to answer the claims of Inverness, failed to attend subsequent meetings and were fined $£ 20$. The dispute within the convention was somewhat one sided as the commissioner of Inverness was also the custumar for all burghs between Caithness and Moray.

${ }^{33}$ While the translation is often described as 'recorded', there is no trace of it (Munro and Munro, Tain, 16).

34 Aberdeen Breviarium, ii. fo. 65r., esp. the eighth and ninth lessons. 
A second legend first appears in Duthac's canonisation petition, drafted by James Haldenstone, prior of St Andrews (1418-43) in 1418. ${ }^{35}$ The two-page letter was probably intended to initiate a canonisation process; but there is no record of a reply or of further correspondence regarding the saint. Haldenstone presented Duthac as an austere episcopal confessor, whose cult, built upon a reputation for miracle working, encompassed the whole kingdom. The letter, because of its formulaic nature, provides only limited information about Duthac's popularity but the second and third points made in the petition appear to have been designed to satisfy the essential criteria for canonisation, as established by the Fourth Lateran Council in 1215. ${ }^{36}$ Another notable aspect of the petition is the connection drawn by Haldenstone between the saint and St Andrews: Haldenstone claimed that Duthac was transferred from Ross to St Andrews. Walter Bower, writing in the 1440s, was also aware of a tradition connecting Duthac to St Andrews, noting that when Duthac was in Ireland he had mentored Maelbrigde, a late eleventh-century bishop of St Andrews. ${ }^{37}$ Bower's source was a life of the saint, perhaps a new vita commissioned as part of the canonisation process of $1418 .^{38}$

The designation of Duthac as a bishop of St Andrews is unsubstantiated. ${ }^{39}$ Although McRoberts has explained the petition of 1418 as an example of the growing concern for Scottish saints in the fifteenth century, Haldenstone may have had more specific reasons for promoting Duthac. ${ }^{40}$ Initially a supporter of the Avignon pope Benedict XIII (1394-1417), Haldenstone had switched his allegiance to Martin V (1417-31) shortly before his election as prior in 1417. Haldenstone subsequently became a spokesman for Martin's supporters, who prevailed in 1418 when support was officially withdrawn from Benedict. ${ }^{41}$ In February 1418, two months before the petition was dated, Martin V provided Griffin Young, an exiled Welsh

35 The petition was intended for presentation to Martin V by Archibald, earl of Douglas (J.H. Baxter (ed.), Copiale Prioratus Sanctiandree (Oxford, 1930), 4-6, 385).

36 On the canonisation process, see A.M. Kleinberg, 'Proving sanctity: selection and authentication of saints in the later middle ages', Viator 20 (1980) 183-205. Posthumous miracles and acceptance of sanctity over a wide area were required for canonization.

37 Bower also noted that Duthac's prophecy that Maelbrigde would one day become bishop (D.E.R. Watt (ed.), Scotichronicon by Walter Bower in Latin and English, 9 vols (Aberdeen, 1987-99), [Chron. Bower], iii. 345.

${ }^{38}$ Sadly this is no longer extant. Bower did not identify his source (Chron. Bower, iii. 343).

${ }^{39}$ Keith and Eubel identified Duthac as a bishop of Ross in the early thirteenth century: John Dowden, The Bishops of Scotland (Glasgow, 1912), 211-2. Watt noted Duthac as a possible early bishop of Ross but did not include him in the St Andrews list: D.E.R. Watt, Fasti Ecclesia Scoticanae Medii Aevi, ad annum 1638 (Edinburgh, 1969), 347.

${ }^{40}$ McRoberts, 'Scottish church', 9.

${ }^{41}$ D.E.R. Watt, A Biographical Dictionary of Scottish Graduates to 1410 (Edinburgh, 1977), 248-51; R.K Hannay, 'A chapter election at St Andrews in 1417', Scottish Historical Review 13 (1913) 321-7; Robert Swanson, 'The university of St Andrews and the Great Schism, 1410-19', Journal of Ecclesiastical History 26 (1975) 223-61, at 238. 
bishop, who had supported the revolt of Owain Glyn Dŵr, to the vacant see of Ross. Young never occupied the see and he was eventually transferred to the warmer climes of Hippo, to be replaced by a canon of St Andrews, John Bullock, in 1423. By August 1419 it had probably become clear that Young would remain an absentee and a year after the canonisation petition, which had made the association between St Andrews and the northern diocese, Haldenstone was enjoined to sequestrate the fruits of the see of Ross. ${ }^{42}$

It is not clear whether Haldenstone had personal designs on Ross, whether he supported Bullock or whether he was merely after the cash. However, by identifying himself with an emerging local cult Haldenstone appears to have been smoothing the way for his intervention in Ross, a process justified by the creation of a historical connection between St Andrews and the northern see. In both his petition and Bower's chronicle there is also a sense that the writers were keen to bring the cult into the mainstream of the Scottish church by providing Duthac with a place in the narrative of the kingdom's ecclesiastical development. This aim may have been driven by a sense that the Duthac cult, with its Irish connections and firm presence in the Hiberno-Norse world of the north, was almost beyond the control of the main centres of the national church. ${ }^{43}$ The impression that there was an unofficial dimension to the cult is suggested by the description of Duthac as 'the demi-God of Ross' in 1513, a theme to which we will return later. ${ }^{44}$ Still, without independent corroboration the Duthac-St Andrews connection, like the local Tain legend, must also be treated with caution.

A third origin legend, which disregarded the St Andrews connection and located Duthac in the late twelfth and early thirteenth century, was elaborated at length in two post-reformation histories. The first of these was written by John Leslie, exiled bishop of Ross, who was keen to stress the appeal of the saint and his shrine to the royal house and ordinary Scots. ${ }^{45}$ Leslie, like Boece, placed Duthac in the reign of William I (1165-1214), describing him as the mentor of Gilbert of Caithness. ${ }^{46} \mathrm{~A}$ similar timeframe was posited by another exiled churchman in $1631 .{ }^{47}$ David Chambers presented a unique legend in which Duthac predicted Scottish calamities at the hands of the English and Danes and prophesised the victory over the Norwegians at Largs in 1263. He placed the

42 Baxter (ed.), Copiale, 389-90. Bishop Alexander de Wagham died on 4 Feb. 1418; Young was transferred from Bangor on 14 Feb. and John Bullock (Haldenstone's rival for the position of prior in 1417) was provided by Benedict XIII but had to await confirmation by Martin V until 1423 (Watt, Fasti, 268-9).

43 This Hiberno-Norse dimension to the cult was emphasised in the Martyrology of Aberdeen, which described Irish pilgrims at the shrine. See A.P. Forbes (ed.), Kalenders of Scottish Saints (Edinburgh, 1872), 129.

${ }^{44}$ Henry Weber (ed.), Battle of Flodden Field: A poem of the sixteenth century (Edinburgh, 1808), 27.

${ }^{45}$ Cody and Murison (eds), Historie, i. 335.

${ }^{46}$ Gilbert was bishop of Caithness from 1222x23-1245. See Watt, Fasti, 58; Cody and Murison (eds), Historie, i. 335; Chron. Boece, ii. 229.

${ }^{47}$ Chambers, De Scotorum, 112-3. 
death of the saint nine years earlier, in $1253 .{ }^{48}$ Although these accounts were not mentioned in the lessons of the Aberdeen Breviary, Boece too noted the connection with Gilbert, suggesting that it, at least, was a known component of the legends surrounding the saint before the reformation. The comments of Leslie and Chambers should nonetheless be treated with caution. Their remarks were part of a wider counterreformation agenda which was aimed at a royal audience. Leslie was keen to enhance the reputation of both his defeated cause and his diocese while Chambers sought to emphasise the traditional relationship between the Stewart dynasty and popular catholicism, as embodied in the cult of the saints. ${ }^{49}$ Duthac, an establishment figure but also a saint who had been the recipient of popular and royal patronage in the century before the reformation, was an ideal figure for this agenda.

If much remains uncertain about Duthac's origins, the records of his early cult and shrine at Tain are also patchy and problematic and they fail to resolve the ambiguity over the saint's provenance. The church at Tain enters the written records with a reference to Brydinus, the vicar, in $1227 .{ }^{50}$ The shrine is first noted in 1306, when William, earl of Ross (d. 1323), showing a marked lack of respect for the saint, violated the sanctuary and captured Elizabeth and Marjory Bruce and their guardian, John, earl of Atholl. ${ }^{51}$ Beyond Tain, early dates have been suggested for chapels dedicated to Duthac at Wick and Kirkwall but it is difficult to establish these with confidence to before the fifteenth century. ${ }^{52}$ Altars dedicated to Duthac at Ayr and Haddington, posited as the earliest extension of the cult beyond the north, have been tentatively dated to the mid-thirteenth century. ${ }^{53}$ However, the altar in the Dominican friary at Ayr was first recorded in 1517 and there is no reason to suppose that it was founded earlier than the fifteenth century. ${ }^{54}$ The altar in the Franciscan friary at Haddington is the earliest attested dedication to Duthac outside of the north. It may well date from the late thirteenth century but was first recorded in 1314, when it

48 Ibid., 113. In his calendar of Scottish saints Chambers also included what appears to be the local June feast day of the saint: Forbes (ed.), Kalenders, 235, 238.

${ }^{49}$ For Leslie's career, see Cody and Murison (eds), Historie, p. xvii. For Chambers, see B.M. Halloran, The Scots College Paris, 1603-1792 (Edinburgh, 1997), 14, 30-1, 205-6. Leslie's work was dedicated to Mary, queen of Scots (1542-67); that of Chambers was dedicated to Charles I (1625-49).

50 Brydinus, 'Vicar of Tene', is first mentioned in 1227 (Cosmo Innes (ed.), Registrum Episcopatus Moraviensis, Bannatyne Club (Edinburgh, 1837), 82).

51 John Barbour, The Bruce, ed. A.A.M. Duncan (Edinburgh 1997), iv/45-55; John de Fordun, Chronica Gentis Scotorum, ed. W. Skene, 2 vols (Edinburgh, 1871-2) [Chron. Fordun], ii. 334.

52 See Table 1, nos. 12 and 19. The coastal location of these chapels suggests that they may have been part of the mercantile trend in Duthac dedications that will be discussed below.

53 Slade, Collegiate Kirk, 9 suggests that the altars were in the two friaries from their foundations in 1242 and 1230 respectively but there is no evidence to support this.

54 There is no evidence that this altar (see Table 1, no. 3) was founded when the friary was built in 1242 and it is unlikely that a dedication to Duthac was to be found in Ayr at that stage. 
was noted that John Congilton of that ilk's parents were buried next to the altar of St Duthac. ${ }^{55}$ This dedication forms part of a strange cluster of dedications involving the saint in Lothian. In addition to the Haddington altar, James Douglas of Dalkeith included a bequest to the church of Tain in his testament of 1390 and the saint's feast day was included in a liturgical calendar belonging to the Sinclairs of Herdmanston. ${ }^{56}$ There are no references to a Lothian connection for the saint after 1390 and, as we will see, the type of devotee, method of dissemination and style of commemoration within this cluster of dedications would not prove to be characteristic of the late medieval Duthac cult.

Elsewhere other church dedications and place-names have also been associated with St Duthac. ${ }^{57}$ The parish churches of Croy on the Moray Firth and Kintail in Wester Ross were dedicated to the saint, though the earliest references to Duthac as the patron of these churches postdate the reformation. ${ }^{58}$ The cluster of Duthac place-names around the church of Kintail (the village of Clachan Dubhthaich, Loch Duich and the pass of Cadha Dhubhthaich) are a strong indication that the church was dedicated to a saint of that name but it is difficult to be certain of a firm date for these names. ${ }^{59}$ While other place-names (Arduthie, Belmaduthie, Lethen Dubhthach and Kilduthie in the north and Baldutho in Fife) also appear to contain the name Duthac, there is no religious context for these dedications and the sites could be named after other individuals named Duthac. ${ }^{60}$ Although it was not a common

55 W.M. Bryce, The Scottish Grey Friars (Edinburgh, 1909), 170, 177; Robert Douglas, The Baronage of Scotland (Edinburgh, 1798), 521. There are no references to Duthac in the extant documents relating to the Greyfriars in Haddington. It is possible that the altar did not survive the destruction of the church in 1355 (Edinburgh, National Records of Scotland [NRS], GD1/413/25 (Charters, writs and notices of the Grey Friars of Haddington); B30/21/39 (Haddington Burgh Charters). There was an image, but no altar, of St 'Doicho', probably the saint of Tain, in the parish church of Haddington from 1530 (NRS, GD98/11/8 (Douglas Collection, 1375-1923)).

56 Bannatyne Miscellany, 3 vols, Bannatyne Club (Edinburgh, 1836-55), ii. 109; Thomas Thomson (ed.), Registrum Honoris de Morton, 2 vols, Bannatyne Club (Edinburgh, 1853), ii. 170-6, 179-86; Forbes (ed.), Kalenders, 35-49, at 38, 43. For other feast days associated with Duthac, see R.J. Adam (ed.), Calendar of Ferne: Texts and additions, 1471-1667 (Edinburgh, 1991), 53; Edinburgh University Library [EUL], MS 27, fo. 2; C.R. Borland (ed.), A Descriptive Catalogue of the Western Medieval Manuscripts in Edinburgh University Library (Edinburgh, 1916), 38-9.

57 Watson, CPNS, 283-4, W.J. Watson, Scottish Place Name Papers (London, 2002), 219; Mackinley, Ancient Church Dedications, 226-7.

58 The dedication of the Croy church is mentioned in the earliest surviving kirk session records from 1640 (NRS, CH2/76 (Records of Croy Kirk Session)). The dedication of at Kintail is mentioned by Mackinley and Watson but first attested in 1600 (Watson, CPNS, 284; Mackinley, Ancient Church Dedications, 226; I.B. Cowan, The Parishes of Medieval Scotland Scottish Record Soc. (Edinburgh, 1967), 116).

${ }^{59} \mathrm{I}$ am grateful to Simon Taylor for this suggestion and for other comments on church and place-name dedications connected to the saint.

${ }^{60}$ For Arduthie, near Aberdeen, Belmaduthie, in the Black Isle, Lethen Dubhthach, near Forres, and Kilduthie, in Kincardineshire, see Mackinley, Ancient Church Dedications, 226; Watson, CPNS, 284. For Baldutho in eastern Fife, see Simon Taylor and Gilbert. Markus (eds), The Place-Names of Fife, 5 vols (Donington, 2009), iii. 140. 
name, there are examples of its use in ninth-century Iceland, in Ireland and on tenth-century Iona, as well as in the later middle ages. ${ }^{61}$ So, while the early church records and place-name evidence confirms that the Tain shrine existed by 1306 and that the cult first appeared outside the north around the same time, they neither fully support, nor rule out, either the eleventh or the thirteenth-century timeframes posited in the origin legends.

Although these legends reveal more about the ambitions and anxieties of those involved in their transmission than the actual origins of saint and cult, they do have some material in common. What emerges from these sources is a basic narrative, similar to that recorded in the Aberdeen Breviary, of a cult established around a holy man with Irish connections, who was based in the Dornoch firth area for at least part of his career. Although he was consistently described as a bishop in later sources, this may be attributed to the tendency in the central and later middle ages to incorporate saints into the church establishment or secular elite, a trend also apparent in the description of Duthac's noble roots in the Aberdeen Breviary. ${ }^{62}$ What is also clear from the various legends is that something significant in the cult's development occurred in the early to mid-thirteenth century. ${ }^{63}$ This may have prompted Boece, Leslie and Chambers to conclude that Duthac had a late twelfth and early thirteenth-century provenance. The event may have been a relic translation from Armagh to Tain, as local tradition suggests, or merely a change to Duthac's status within the reliquary church.

This event-whatever it was-ties in with the spectacular rise of a local family led by Fearchar mac an t-sagairt, who was made earl of Ross by Alexander II (1216-49) in the 1220s. ${ }^{64}$ Alexander Grant has suggested that Fearchar, whose name means 'son of the priest', was from a family of hereditary clergy in Tain. ${ }^{65}$ A grateful man, newly prominent at court, perhaps even promoting the cult of an ancestor, would neatly explain both a translation in this period and the transmission of the cult beyond the north. Unfortunately, this premise does not stand up to further examination. Although Fearchar apparently died

61 A slave called Dubthach is recorded in Iceland in $870 \times 3$ and sons of an Irishman called Dutthak were on the same island in $870 \times 900$. In the Senchus Fer $n$-Alban, Dubthach was a son of Erc Eochaid's son $(E S$, i. $335,345,430)$. $A U, 456$ records the death of Dubthach, abbot of Iona, in 938. Dubthach, an Irish poet, is also mentioned in Charles Plummer (ed.), Vitae Sanctorum Hiberniae, 2 vols (Dublin, 1997), i. p. cxxviii. A possible appearance of the name in lowland Scotland during this period is a Duftah, Céile Dé abbot of Lochleven in 1128 (A.C. Lawrie (ed.), Early Scottish Charters prior to A.D. 1153 (Glasgow, 1905), no. 80). The appearance of the name in the later middle ages is discussed below.

62 Vauchez, Sainthood, 173-7; Swanson, Religion and Devotion, 148, describes the most common saint type between 1215 and 1515 as the well born who had held high ecclesiastical office.

63 The date 1253 appears in several local histories and Chambers, De Scotorum, 112-3.

64 A.A.M. Duncan, Scotland: The making of the kingdom (Edinburgh, 1975), 520.

65 Alexander Grant, 'The province of Ross and the kingdom of Alba', in E.J. Cowan and R.A. McDonald (eds), Alba: Celtic Scotland in the medieval era (East Linton, 2000), 88-126, at 120-3. Recent work on Tain refutes this suggestion: Cathcart et al. (eds), Historic Tain, 20-1. 
in Tain, he was buried at his own foundation, the Premonstratensian priory of New Fearn, and neither he, nor his descendants, displayed a conspicuous interest in Duthac or Tain. ${ }^{66}$ While Fearchar may not have been responsible for the event of $c$. 1253, it does appear to have raised the profile of the shrine, leading Barbour and the other chroniclers to identify Tain as 'St Duthac's town' when recording the incident that occurred there in 1306.

The Duthac cult may have been based around the confessor who died in Armagh in 1065; or around Dubthach, abbot of Iona, who died in 938; or around one of two Irish saints with similar names who feature in the Martyrology of Donegal. ${ }^{67}$ While it may be impossible to provide firm conclusions on the 'historical' Duthac, exploring the various legends surrounding the saint is a valuable exercise as they provide rich material on both the reception of the saint during his period of greatest popularity and the aims of those involved in propagating the cult. However, the legends, the early church dedication, literary and placename evidence, fail to indicate an obvious catalyst for the mutation of what appears to have been a local cult in Ross and Caithness into a saint with national appeal. It was instead the interests of a particular group of Scots in the late fourteenth and fifteenth centuries that transformed Duthac into this national figure.

There were numerous saints in medieval Europe. The Aberdeen Breviary included as many as eighty-one considered to have had a connection to Scotland but it was a rare few to whom veneration was manifested on more than a local level. ${ }^{68}$ The diffusion of the Duthac cult throughout later medieval Scotland was, therefore, unusual and remarkable. One measure of Duthac's popularity is the consistent marking of his feast day in corporate and personal calendars. ${ }^{69}$ Duthac was one of around ten Scottish saints whose feasts appeared regularly in these calendars. ${ }^{70}$ However, in contrast to other saints from this group

66 The seat of the earls of Ross was at Delny, close to Tain. Although it is possible that Fearchar had an interest in moving the diocesan centre from Rosemarkie to Duthac's town, he is most closely related to the abbey of Fearn, where he was buried in 1252 (I.B. Cowan and David Easson, Medieval Religious Houses: Scotland (Edinburgh, 1976), 101; Munro and Munro, Tain, 16; Slade, Collegiate Kirk, 21-2). Fearn was a daughter house of the Premonstratensian abbey of Whithorn and was founded by Fearchar, who endowed it with a relic of St Ninian probably sometime after 1235 when he was involved in the royal campaign in Galloway (Duncan, Scotland, 531).

67 There were two Dubthachs in the Martyrology with feast days on 5 Feb. and 7 Oct. (John O'Donovan (ed.), Martyrology of Donegal: A calendar of saints of Ireland (Dublin, 1864), 40-1, 268-9).

68 Alan Macquarrie, 'Scottish Saints' legends in the Aberdeen Breviary's, in Boardman and Williamson (eds), Cult of Saints, 143-57.

69 Overall Duthac features in 63\% (seventeen out of twenty-seven) of the extant Scottish liturgical documents which feature local saints in their calendars from the late fourteenth century to the reformation. See T.J.M. Turpie, 'Scottish Saints, Cults and Pilgrimage from the Black Death to the Reformation', unpublished Ph.D. thesis (University of Edinburgh, 2011), 17-21.

70 A core group of ten local saints feature regularly in these calendars. In addition to the four mentioned above, these include Andrew, Ninian, Columba, Kentigern, Monan of Inverey and Fillan of Strathfillan (ibid, 20-5). 
(such as Constantine of Govan, Monan of Inverey, Kessog of Luss and Baldred of Tyninghame), there is plentiful additional evidence of active and wide devotion to the saint of Tain (see Table 1). Aside from the puzzling altar in Haddington, the earliest recorded Duthac dedication was in Aberdeen, where an altar was founded by two burgesses, Laurence de Crag and John Scherer, in 1359 (no. 1). Aberdeen would become something of a secondary centre for the cult in the later middle ages, with a well financed altar under the patronage of the Scherer family and a relic and image of the saint in the burgh church. ${ }^{71}$ Wider devotion to Duthac in the burgh was reflected by a small cluster of men named after the saint in the late fourteenth century. They included Duthac Carnegie, a burgess and local landowner who perished at Harlaw in 1411, and his contemporaries, Barker and Lowman, burgesses first attested in 1398-1400. ${ }^{72}$ The early provenance of these men-Carnegie is first recorded witnessing a charter in 1363-in conjunction with the small cluster of place-name dedications in the north-east, suggest that the cult was known in Aberdeen before the founding of the altar in 1359. ${ }^{73}$

The dedication in Aberdeen was the first in a succession of altars founded in towns in honour of Duthac. Indeed, the primary catalyst for the spread of Duthac's cult from Tain was the interest of prominent townsmen. This urban and mercantile connection to the cult is further emphasised by the otherwise inexplicable presence of two burgesses, David Menzies of Edinburgh and James Levingtoune of Aberdeen, in Tain in 1487, witnessing the royal charter that conferred collegiate status on the church. ${ }^{74}$ It is not obvious what prompted the urban interest in Duthac but towns provide a strong clue as to how his cult was transmitted. The earliest recorded dedication, aside from the small cluster in Lothian, was the Aberdeen altar, founded in $1359 .^{75}$ Aberdeen

71 The first altar was established by Lawrence de Crag and John Scherer in 1359; it was adorned with an image of the saint. The relic is mentioned in several inventories of St Nicholas's parish church from 1436 but not in the reliquary collection of St Machar's cathedral, as suggested by Slade, Collegiate Church, 9. For the relic, see Cosmio Innes (ed.), Registrum Episcopatus Aberdonensis, 2 vols, Spalding Club (Aberdeen, 1845) [Aberdeen Reg.], ii. 143, 160. The altar was further endowed by John Scherer's grandson, William, and others in 1464 (Jacobus Cooper (ed.), Cartularium Ecclesiae Sancti Nicholai Aberdonensis, 2 vols, New Spalding Club (Aberdeen, 1888-92), [St Nich. Cart.], ii. 17-18). The chaplaincy remained under the control of the Scherers until 1630 (ibid, ii. 297).

72 Duthac Carnegie was second son of John de Balinhard, the progenitor of the Carnegie earls of South Esk. He owned lands in Angus (J.B. Paul (ed.), Scots Peerage, 9 vols (Edinburgh, 1911), viii. 46-9; Aberdeen Reg., 284; William Fraser, History of the Carnegie Earls of South Esk and of their Kindred (Edinburgh, 1867), 9-14). For Barker and Lowman, see W.C. Dickinson (ed.), Early Records of the Burgh of Aberdeen, 1317, 1398-1400, Scottish Hist. Soc. (Edinburgh, 1957), 94, 103, 185, 223, 232.

73 Fraser, Carnegie Earls of South Esk, 29-32. Lowman and Barker were first recorded in 1398 and may have been born after the altar was founded in 1359.

74 The charter was witnessed in Tain on 12 Sept. and confirmed in Edinburgh on 3 Dec. ( $R M S$, ii. no. 1694). It is possible that these men were in Tain on pilgrimage. The other witnesses were all churchmen: the abbot of Fearn, a deacon of Caithness, three members of the Ross cathedral clergy and a canon from Moray.

75 St Nich. Cart, i. 15. 
was the commercial and political hub of the north and grain arrived there from Ross and Caithness throughout the period. ${ }^{76}$ It was perhaps

Table 1: Dedications to St Duthac in Late Medieval Scotland

\begin{tabular}{|c|c|c|c|c|}
\hline & Location & $\begin{array}{l}\text { Dedication } \\
\text { type }\end{array}$ & $\begin{array}{l}\text { founded/ } \\
\text { first attested }\end{array}$ & $\begin{array}{l}\text { founder/ } \\
\text { patron }\end{array}$ \\
\hline 1 & $\begin{array}{l}\text { Aberdeen, } \\
\text { St Nicholas }\end{array}$ & altar & 1359 & $\begin{array}{l}\text { Lawrence de Crag, } \\
\text { John Scherer } \\
\text { (burgesses) }\end{array}$ \\
\hline 2 & Arbroath Abbey ${ }^{78}$ & altar & 1524 & $\begin{array}{l}\text { Robert Scot } \\
\text { (burgess) }\end{array}$ \\
\hline 3 & Ayr, Dominican friary ${ }^{79}$ & altar & by 1517 & \\
\hline 4 & Brechin Cathedral $^{80}$ & altar & 1485 & $\begin{array}{l}\text { Malcolm Guthrie } \\
\text { (burgess) }\end{array}$ \\
\hline 5 & Dundee, St Mary ${ }^{81}$ & altar & 1516 & $\begin{array}{l}\text { Skinner/Glovers } \\
\text { guild }\end{array}$ \\
\hline 6 & $\begin{array}{l}\text { Edinburgh, } \\
\text { Holyrood Abbey }^{82}\end{array}$ & light & by 1511 & James IV? \\
\hline 7 & Edinburgh, St Giles ${ }^{83}$ & altar & 1438 & $\begin{array}{l}\text { Thomas Cranstoun } \\
\text { (provost/merchant) }\end{array}$ \\
\hline 8 & Elgin Cathedral $^{84}$ & altar & by 1528 & $\begin{array}{l}\text { Alexander Garderer } \\
\text { (burgess) }\end{array}$ \\
\hline 9 & Forres $^{85}$ & chapel & by 1611 & \\
\hline
\end{tabular}

76 Ian Blanchard et al., 'The economy: town and country', in Patricia Dennison, David Ditchburn and Michael Lynch (eds), Aberdeen Before 1800: A new history (East Linton, 2002), 129-58, at 153, 156. See too H.W. Booton, 'Inland trade: a study of Aberdeen in the late middle ages', in Michael Lynch, Michael Spearman and Geoffrey Stell (eds), The Scottish Medieval Town (Edinburgh, 1988), 148-61, at 148.

77 St Nich. Cart., i. 15.

78 Cosmo Innes (ed.), Liber St Thome de Aberbrothoc: Registrum abbacie de Aberbrothoc, 2 vols (Bannatyne Club, Edinburgh, 1848-56), [Arbroath Reg.], ii. 438-42.

79 John Anderson and F.J. Grant (eds), The Protocol Book of Gavin Ros, Scottish Record Soc. (Edinburgh, 1908), 28; David Murray, Legal Practice in Ayr and the West of Scotland in the Fifteenth and Sixteenth Centuries (Glasgow, 1910), 27.

${ }^{80}$ Cosmo Innes (ed.), Registrum Episcopatus Brechinensis, 2 vols, Bannatyne Club (Aberdeen, 1856), ii. 120.

81 Alexander Maxwell, Old Dundee: Ecclesiastical, burghal and social, prior to the reformation (Edinburgh, 1891), 29.

82 The only record of this light is an offering made by James IV in Dec. 1511 (Thomas Dickson and J.B. Paul (eds), Accounts of the Lord High Treasurer of Scotland, 12 vols (Edinburgh, 1877-1916) [TA], iv. 181.

83 David Laing (ed.), Registrum Cartarum Ecclesie Sancti Egidii de Edinburgh, Bannatyne Club (Edinburgh, 1859), 59, 65, 67, 69, 76. There is also evidence for use of the personal name Duthac in Edinburgh. Duthac Wigmore was involved in the upkeep of both the high altar and of the chaplain of St Michael's altar in St Giles (ibid., 77 and 104). Duthac Ker, an Edinburgh burgess, was recorded in 1482 (Cosmo Innes (ed.), Registrum S. Marie de Neubotle Bannatyne Club (Edinburgh, 1849), 275-6).

${ }^{84}$ RMS, iii. no. 781.

85 The chapel dedicated to the saint in Forres is first mentioned in 1611 (RMS, vii. no. 519). 
Table 1: Continued

\begin{tabular}{|c|c|c|c|c|}
\hline & Location & $\begin{array}{l}\text { Dedication } \\
\text { type }\end{array}$ & $\begin{array}{l}\text { founded/ } \\
\text { first attested }\end{array}$ & $\begin{array}{l}\text { founder/ } \\
\text { patron }\end{array}$ \\
\hline 10 & $\begin{array}{l}\text { Haddington, } \\
\text { Franciscan friary }\end{array}$ & altar & by 1314 & $\begin{array}{l}\text { John Congilton of } \\
\text { that Ilk }\end{array}$ \\
\hline 11 & Kelso Abbey ${ }^{87}$ & altar & by 1505 & $\begin{array}{l}\text { Thomas Brown } \\
\text { (priest) }\end{array}$ \\
\hline 12 & Kirkwall $^{88}$ & chapel & by 1448 & Sinclair family \\
\hline 13 & $\begin{array}{l}\text { Inverness, } \\
\text { Dominican friary }\end{array}$ & altar & by 1560 & \\
\hline 14 & $\begin{array}{l}\text { Linlithgow, } \\
\text { St Michael }^{90}\end{array}$ & altar & c. 1488 & James IV? \\
\hline 15 & Newburgh $^{91}$ & $\begin{array}{l}\text { church } \\
\text { (joint dedication) }\end{array}$ & 1508 & \\
\hline 16 & Perth, St John ${ }^{92}$ & altar & by 1515 & \\
\hline 17 & Restalrig $^{93}$ & $\begin{array}{l}\text { chapel } \\
\text { (joint dedication) }\end{array}$ & 1487 & James III \\
\hline 18 & $\begin{array}{l}\text { St Andrews, } \\
\text { Holy Trinity }{ }^{94}\end{array}$ & altar & 1481 & $\begin{array}{l}\text { Andrew Martin } \\
\text { (canon) }\end{array}$ \\
\hline 19 & Wick $^{95}$ & chapel & & \\
\hline
\end{tabular}

86 The earliest reference to this altar is Douglas, Baronage of Scotland, 521, citing a now lost family archive. Bryce, Grey Friars, i. 170, 177 cites this reference, noting the charter of 1314 in which John Congilton donated bread and wine to the Duthac altar for the souls of his parents who were buried beside it. J.G. Wallace refers to a charter of 1314 in NRS, GD1/413/25 (Charters, writs and notices of the Grey Friars of Haddington) but this is no longer extant.

87 Thomas Brown, vicar of East Calder, founded a chaplainry at the pre-existing altar of St Duthac in the abbey in 1505 (RMS, ii. no. 2860).

88 The chapel in Orkney is first mentioned in 1448 (J.B. Craven, A History of the Episcopal Church in the Diocese of Caithness (Kirkwall, 1908), 101-4; Alexander Peterkin (ed.), Rentals of the Ancient Earldom and Bishopric of Orkney (Edinburgh, 1820), 35, 167-8.

89 The altar in the Dominican friary of Inverness was first recorded in 1560 (John Stuart et al. (eds), Exchequer Rolls of Scotland, 23 vols (Edinburgh, 1878-1908) [ER], xix. 351, $391)$.

90 The only information for this altar comes from the patronage of James IV (John Ferguson, Ecclesia Antiqua, or the History of an Ancient Church: St Michael's, Linlithgow (Edinburgh, 1905), 327; TA, i. 337).

91 The burgh church of Newburgh was dedicated jointly to Katherine, Mary Magdalene and Duthac (Alexander Laing, Lindores Abbey and its Burgh of Newburgh. Their history and annals (Edinburgh, 1876), 156, 512).

92 An instrument from the protocol book of Robert Thomsoun was witnessed by William, Lord Ruthven, provost of Perth, before the altar of St Duthac in the parish church (NRS, GD112/25/6 (Breadalbane Muniments)).

93 David Laing (ed.), Registrum Domus de Soltre, necnon Ecclesiae Collegiate S. Trinitatis prope Edinburgh, 2 vols, Bannatyne Club (Edinburgh, 1861), i. 282.

94 The Duthac altar was apparently already in existence before it was refounded in 1481 by Andrew Martin, a canon of Aberdeen (NRS, GD241/198 (Records of Thomson and Baxter). For the other Martin brothers who further endowed it in 1487, see W.E.K. Rankin, The Parish Church of Holy Trinity St Andrews (Edinburgh, 1955), 76-7.

95 The Wick chapel is problematic and no dating is possible (Origines Parochiales Scotiae, 3 vols (Edinburgh, 1855), ii. 772-3; Craven, Episcopal Church, 5). 
through Aberdeen that the cult spread along seaborne trading routes to Edinburgh, where the Duthac altar was founded in 1438, and to other east-coast burghs.

Royal interest in the saint developed after the cult spread south. The earliest connection between the royal house and the saint of Tain can be traced to 1306 when the wife and daughter of Robert I (1306-29) were captured at his shrine. As a punishment for this action William, earl of Ross, was forced to pay chaplains to say masses at Tain for the soul of John, earl of Atholl, who was executed shortly after his capture with Bruce's family. ${ }^{96}$ This was one of several similar 'spiritual' punishments meted out by the king but it is not indicative of an active Bruce interest in the cult. ${ }^{97}$ Further crown engagement with Duthac and Tain is not recorded until the $1450 \mathrm{~s}$, when the stimulus for this renewed patronage seems to have been conflict with the Black Douglases. ${ }^{98}$ The Douglases held lordships in the north, including extensive estates in the Black Isle, south of Tain. ${ }^{99}$ Douglas engagement with the Duthac cult is implied by the involvement of Archibald, earl of Douglas, in Haldenstone's canonisation petition of 1418 though there is little other evidence of the family's interest in Duthac. ${ }^{100}$ Following the crown's annexation of the northern Douglas estates in 1455, James II seems to have viewed patronage of the cult as a means by which to establish royal control in the region. ${ }^{101}$ In 1456 and 1457 the king toured the north, staying at Inverness, Elgin and Aberdeen, and he perhaps came into contact with the cult in these burghs, where dedications to the saint could be found. ${ }^{102}$ It was during his second visit to the north in 1457 that James made the first of a series of grants to the shrine, endowing a chaplainry in the newly built church at Tain with an annual subsidy of $£ 6 .{ }^{103}$

Royal patronage was continued by James III (1460-88), who seems to have developed a more personal connection to the saint, perhaps even visiting the shrine with his queen during their honeymoon progress

96 This payment was made in 1321 (A.A.M. Duncan (ed.), Regesta Regum Scottorum V: The Acts of Robert I, 1306-29 (Edinburgh, 1986), no. 196).

97 G.W.S. Barrow, Robert Bruce and the Community of the Realm of Scotland (Edinburgh, $4^{\text {th }}$ edn, 2005), 413 .

98 A similar trend can be seen in crown engagement with SS. Ninian and Kentigern which can also be traced to James II's reign; see Turpie, 'Scottish Saints', 82-92 and 190-5.

99 These were the estates of Avoch and Eddirdovar, collectively known as the barony of Ardmeannach, which were converted into the earldom of Ormond for a brother of the eighth earl of Douglas in 1443. These lands came into the possession of the Douglases following the marriage between Archibald Douglas (the future third earl) and Joanne Murray in 1362 (Michael Brown, The Black Douglases (East Linton, 1998), 96-7, 254, 267).

100 Baxter (ed.), Copiale, 4-6, 385. As already noted, James Douglas of Dalkeith, made a grant to Tain in his will of 1390 (Bannatyne Miscellany, ii. 109).

101 For the annexation of these lands, see APS, ii. 41-3.

102 Christine McGladdery, James II (Edinburgh, 1990), 104-5.

103 The first subsidy was provided from the lands of Dunscathe in Ross (ER, vi. 465). 
through the north in $1470 .{ }^{104}$ In 1476 James annexed the earldom of Ross, in which the shrine was situated, depriving the MacDonalds, under whose control it had been since the $1430 \mathrm{~s} .{ }^{105}$ This provided a further stimulus for crown patronage of the cult. The king used the fermes of the earldom to pay the chaplain and town provost from 1479 and a further chaplaincy at the church was endowed in 1482. ${ }^{106}$ James also supported Tain's new collegiate status in 1487 and he included Duthac among the patrons of his new foundation at Restalrig in the same year (no. 17). ${ }^{107}$ Earlier the MacDonalds had presided over the Tain inquest in 1439. They contributed to the building of the new church in 1457 and as late as 1468 made grants of land to the local clergy. ${ }^{108}$ With his sponsorship of Tain, James seems to have been consciously supplanting MacDonald lordship in Ross by assuming the role of patron of the main pilgrimage centre in the region.

The better known devotion of James IV to Duthac must be viewed in the context of continuing Stewart-MacDonald conflict. The final forfeiture of the MacDonald lordship of the Isles occurred in 1493 and was soon followed by a military campaign in the west. ${ }^{109}$ The king's first known pilgrimage to the shrine took place in October of that year, just two months after this military action. ${ }^{110}$ Once James attained his majority these visits became almost annual, placing the king in a region which, following the crown annexation of the earldom of Ross in 1476 , would be wracked by thirty years of intermittent warfare. ${ }^{11}$ The journeys through the north allowed James to coordinate military action and communicate with his lieutenants, as in 1506, when he paused in Badenoch to lend support to those dealing with the Donald Dubh

104 James was in Inverness with his new wife between 23 Jul. and 24 Aug. and could conceivably have visited Tain, less than one day's journey to the north $(E R$, viii. 80 , 85; Macdougall, James III, 89-90, 364).

105 Norman Macdougall, 'Achilles' heel? The earldom of Ross, the lordship of the Isles and the Stewart kings, 1449-1507', in Cowan and McDonald (eds), Alba, 249-51; Macdougall, James III, 128-30.

106 ER, viii. 596; RMS, ii. no. 1513 .

107 The other patrons of Restalrig were Triduana, Mary, Andrew, Ninian and Jerome. For Tain, see RMS, ii. no. 1694; Durkan, 'Sanctuary', 150-4.

108 Macgill (ed), Tain, 369; ER, vi. 465; Munro and Munro (eds), Acts, 43-4, 152. A supporter of the MacDonalds, Alexander Sutherland of Dunbeath, also left money in his will of 1456 to pay for masses at the church of St Duthac (Bannatyne Miscellany, iii. 91).

109 Macdougall, James IV, 101-2.

${ }^{110}$ James was in Dingwall, having recently visited the shrine in October 1493 (RMS, ii. no. 2181 ; $T A$, i. p. xiv). It was presumably for this pilgrimage that he received the victuals recorded in $E R$, x. 439.

111 The king is recorded at Tain in Mar. and Jul. 1496, Mar. 1497, Oct. 1498, Oct. 1501, Oct. 1504, Oct. 1505, Sep.1506, Aug. and Oct. 1507, Oct. 1509, after Easter 1510, May 1511 and Aug. 1513 (TA, i. 258, 260, 322-5, 362-4; ii. 123-6, 265-6, 464, 467; iii. $66,81,282,294,412-16$; iv. 419, 436; $E R$, xiii. 12-13, 203, 209, 288, 292; $R M S$, ii, no. 3575). There is indirect evidence of three further visits to the shrine. James is likely to have been on his way to, or from, Tain when he granted charters at Elgin (Nov. 1494), Inverness (Oct. 1499) and Fortrose (Sept. 1506) (RMS, ii. nos. 2224, 2505, 2991). For conflict in Ross, see Macdougall, 'Achilles' heel?', 261. 
rebellion. ${ }^{112}$ In the summer following the defeat of the Islemen, James used a pilgrimage to the shrine as a propaganda stunt to underline his control of the region. The king 'raid alane to the Month', completing the journey from Edinburgh to Tain in only two days and without an escort. ${ }^{113}$ A more typical visit occurred in 1504, when the king made a leisurely three-week progress through the north with a large entourage, including his Italian minstrels and African drummer. ${ }^{114}$ Generous gifts were distributed on the way. Visits such as this, in addition to the gifts of several ornate reliquaries to the shrine, presented an image of power and munificence to the local populace that the Ross and MacDonald kindreds could not match. ${ }^{115}$

Strategic political aims in the north were not, however, the exclusive motivation for crown patronage of the Duthac cult. James IV continued to show conspicuous interest in the saint and shrine in the latter part of his reign, after the defeat of Donald Dubh's rebellion and temporary settling of the Isles problem. This personal devotion to Duthac, manifested in more pilgrimages to Tain, observance of the saint's feast day and the acquisition of relics, was grander in scale than that shown to other local saints in the period and was comparable to crown patronage of St Ninian and his shrine at Whithorn. ${ }^{116}$ It constituted recognition that the Duthac cult had developed a national significance by the end of the fifteenth century. The relationship between crown and saint did not, however, perish at Flodden. James $\mathrm{V}$ visited Tain on at least four occasions, in 1533, 1534, 1535 and 1537 , and he presented a silver reliquary to the shrine. ${ }^{117}$ By the $1530 \mathrm{~s}$ devotion to the saint and his shrine in Tain had become something of a royal custom, a tradition perhaps given a sharper focus following further risings in the Isles in 1513-15, 1516-19, 1529-33 and 1539. ${ }^{118}$

112 Ibid., 274.

113 James received a purse of $£ 26$ for his journey (TA, iii. 294, 412-16). This unlikely pilgrimage is described in Cody and Murison (eds), Historie, ii. 124 but, as Macdougall has shown, it is borne out by the Treasurer's Accounts (Macdougall, James IV, 293-4).

$114 T A$, ii. 265-6; 462-5.

115 For the reliquaries, see $T A$, i. 282, 322; ii. 376; iii. 80, 28; iv. 40, 553.

116 See n. 111 above. Payments to Duthac lights and altars on his feast day were made at Dysart, St Giles (Edinburgh) and Holyrood Abbey (TA, iii. 285, 287; iv. 39, 18). Masses for the saint were paid for in Linlithgow, Tain and elsewhere (TA, i. 276, 303, 337, 363). A gilded relic and silver cross were gifted to the shrine in 1496 (TA, i. 282, 322 ) and a further relic was mended and offered at the shrine in 1506 (TA, iii. 80, 280). The shirt first turned up in the royal collection in 1512 (TA, iv. 354).

117 The pilgrimage of 1533 has been overlooked. A letter from Thomas Clifford, keeper of Berwick, to Henry VIII recorded that in July of that year James was 'in the north parties of Scotland at a place called Saynt Dothons in Rose' (R.H. Brodie (ed.), Letters and Papers, Foreign and Domestic, of the Reign of Henry VIII, 8 vols (London, 1920), iv. 652-3). For the other pilgrimages see NRS, E31/5 (Libri Domicilii), fos. 45v, 99v; E31/7, fos. 108r; E32/5 (Libri Emptorum), fos. 26v-36r; E32/6, fo. 121r. For a broader discussion of the pilgrimage itinerary of James V, see Andrea Thomas, Princelie Majestie: The court of James V of Scotland, 1528-1542 (Edinburgh, 2005), 114-15. For the reliquary see $T A$, vi. 211,248 .

118 Thomas, Princelie Majestie, 115; Roger Mason, 'Renaissance monarchy? Stewart kingship, 1469-1542', in Michael Brown and Roland Tanner (eds), Scottish Kingship, 
It was political and religious change after 1542, rather than shifting fashions, that broke the connection between the saint and the royal house.

Royal patronage of Duthac gave the cult a greater national and international profile, particularly from the reign of James IV. This was reflected in the inclusion of the saint in a northern English poem from 1513, in which 'Doffin their demi-God of Ross' was listed alongside Ninian and Andrew, as one of Scotland's patron saints at the time of the Flodden campaign. ${ }^{19}$ A generation later, in 1550, 'Duthow' was one of a small group of saints included in a satirical work by David Lindsay, in which he condemned contemporary trends in lay piety. ${ }^{120} \mathrm{It}$ was also in this royal context that post-reformation writers such as John Leslie and David Chambers chose to remember the saint. ${ }^{121}$ However, the direct influence of royal patronage on the spread of the cult, except at Restalrig, Linlithgow and perhaps Newburgh, is difficult to quantify. Although the saint became a clear royal favourite, there is little evidence that his cult had become fashionable at the court. Altars and other dedications to the saint after 1488 were still predominantly founded by burgesses and the small number of individuals named after the saint were mainly tenant farmers or townsmen. ${ }^{122}$ Although royal patronage was a catalyst for the expansion of the cult in the later middle ages, it should probably not be considered the most significant factor in the process. $^{123}$

118 (Continued) 1306-1542: Essays in honour of Norman Macdougall (Edinburgh, 2008), 255-78, at 266; Macdougall, 'Achilles' heel?', 275; James Cameron, James V: The personal rule, 1528-1542 (East Linton, 1998), 255-85.

119 The anonymous English poet lamented the Scots' decision to ignore their patron saints (Andrew, Ninian and Duthac) and embark on war with England (Weber (ed.), Battle of Flodden Field, 27).

${ }^{120}$ In the poem 'Ane Dialog betwix Experience and ane Courteour of the Miserabyll Estait of the World' Lindsay describes 'Duthow' as 'boird out of ane bloke', suggesting that he was referring to a wooden statue of the saint. In addition to Duthac, only four recognisably Scottish saints feature in the poem: Ninian, Andrew, Kentigern and Triduana (David Laing (ed.), Works of Sir David Lyndsay of the Mount, 3 vols, Scottish Text Soc. (Edinburgh, 1879), iii. 270/2302).

121 Leslie includes two stories based around royal pilgrimages to Tain (Cody and Murison (eds), Historie, ii. 124, 133.

122 In addition to the Aberdeen and Edinburgh burgesses already noted, Duthac Scot paid rent for land in the barony of Doune until 1492 (ER, ix. 565, 598, 620, 721). The murder of Duthac Rutherford in 1495 came before a trial at Jedburgh (Robert Pitcairn (ed.), Criminal Trials in Scotland, from A.D. M.CCCC.LXXXVIII to A.D. M.DC.XXIV (Edinburgh, 1833), 26. Doththo Baxter, burgess of Dunfermline, was recorded as deceased by 1488 (Erskine Beveridge (ed), Burgh Records of Dunfermline, 1488-1584 (Edinburgh, 1917), no. 3).

123 A small group of dedications, for which there is no information regarding the founder, do not fit comfortably into the above categories. The altar in the Dominican friary at Inverness could be explained by proximity to Tain, by royal support or by burghal fashion (Table 1, no. 13). The altar at Kelso is difficult to explain (no. 11). The Perth altar (no. 16) was founded late and perhaps followed royal fashion. The chapels in Kirkwall and Wick (nos. 12, 19) may have been part of an early, local spread of the cult, rather than the result of commercial networks. A further northern chapel in Forres (no. 9) was first recorded in 1611. 
Duthac's emergence as a broadly popular saint with a national cult took place between $c .1359$ and 1560, as he became fashionable among the mercantile, urban elite of east coast burghs. Regrettably the devotees of the northern saint seldom felt the need to explain why they chose to favour him. Something of Duthac's appeal can be, however, extracted from the surviving narratives of his life. Like Ninian of Whithorn, the other Scottish saint with a flourishing cult in this period, Duthac seems to have fulfilled a range of specific and general functions for his supplicants. ${ }^{124}$ Haldenstone had emphasised the saint's simple and austere lifestyle and the reputation for the miraculous that surrounded him both in life and death. ${ }^{125}$ This image is expanded in the Aberdeen Breviary, with the key themes of his miracle stories revolving around approachability, gentleness, charity and control over the natural world. ${ }^{126}$ These traits corresponded with the 'neighbourliness and homeliness' that have been identified as distinctive features of the profile of popular saints from late medieval England and France. ${ }^{127}$ The stories in the Aberdeen Breviary are also consistent with what Donald Weinstein characterised as the 'useful' miracles that typified the late medieval saint, as opposed to his more spectacular counterpart from the early middle ages. ${ }^{128}$ The presentation of Duthac as a humane ascetic, with a reputation for practical miracles, placed him firmly in the sainttype described by Duffy as the 'kind neighbour'. ${ }^{129}$

One of Duthac's relics suggests that he also conformed to a second saint-type. The 'hairy shirt' of St Duthac was recorded as part of the royal reliquary collection in 1512 and John Maior detailed its miraculous properties in 1527. ${ }^{130}$ Although the most famous insular example of this relic type was the hair shirt worn by Thomas Becket, such clothing was most commonly associated with hermits and members

${ }^{124}$ Ninian had a winning blend of specific and general thaumaturgical and protective functions, along with a consistent reputation for the miraculous at his Gallovidian shrine and elsewhere. See John Higgitt, 'From Bede to Rabelais: or how St Ninian got his chains', in Paul Binski and William Noel (eds), New Offerings Ancient Treasures: Studies in medieval art for George Henderson (Stroud, 2001), 187-209; Turpie, 'Scottish Saints', 81-110.

125 Baxter (ed.), Copiale, 5-6.

126 Three of Duthac's miracles concerned the charitable distribution of food and two featured inclement weather (Aberdeen Breviarium ii. fo. 65r). These types of miracles also occurred regularly in the Welsh saints' lives explored by Henken, Welsh Saints, 67, 74,80 .

${ }^{127}$ Eamon Duffy, The Stripping of the Altars (London, 1992), 161.

${ }^{128}$ Donald Weinstein and R.M. Bell, Saints and Society: The two worlds of western christendom, 1000-1700 (London, 1982), 144. Stuart Airlie, 'The view from Maastricht', in Barbara Crawford (ed.), Scotland in Dark Age Europe (St Andrews, 1994), 33-46, at 37, described early medieval saints as 'sombre batman type figures, brooding over communities entrusted to their protection'.

${ }^{129}$ Duffy, Stripping of the Altars, 161.

${ }^{130}$ Archibald Constable (ed.), A History of Greater Britain, as well England as Scotland by John Major, Scottish History Soc. (Edinburgh, 1892), [Chron. Maior], 273. The shirt may have been worn by Duthac when he collected coals which he carried home without burning himself or his shirt (Aberdeen Breviarium ii. fo. 65r). James IV had the shirt mended in 1512 (TA, iv. 354). 
of the mendicant orders. ${ }^{131}$ Duthac's shirt and his apparent repudiation of a noble background suggest that the saint may also be allocated to what might be described as the Francis of Assisi saint-type. ${ }^{132}$ This type was related to the 'kind neighbour' and it has been identified as the most prevalent category in Mediterranean countries. ${ }^{133}$ These saints were generally men who had rejected their position in the social elite to lead a life of preaching away from major towns, although, like Duthac, not necessarily in the wilderness. While other Scottish saints could comfortably be allocated to the saint-types of the early Christian apostle (Palladius, Ninian, Columba, and Kentigern), the missionary (Adrian and Monan) or the martyr (Adrian, Constantine and Triduana), Duthac is less easy to classify. The petition of 1418 and the Aberdeen Breviary solved the problem by presenting him as a mendicant-style figure, blending Duthac into a more recognisably northern European model of sanctity by also making him a bishop. ${ }^{134}$

Duthac's affinity with two of the most common and popular sainttypes of the later middle ages may go some way to explaining his particular appeal to the townsfolk and royals. ${ }^{135}$ With his reputation of austerity and desire to lead an exemplary life, Duthac bears similarities to the posthumous repute of Henry VI of England (1422-71), whose gained fame as a practitioner of austere, lay piety. ${ }^{136}$ Duthac's hair shirt may have been of particular significance to this image as Henry, according to his chaplain, had worn one, as had other prominent lay saints, such as St Louis (1214-70). ${ }^{137}$ James IV, of course, famously possessed his own hair shirt and, through his patronage of the Observant Franciscans, he displayed a personal interest in this dour brand of piety. ${ }^{138}$ The unspectacular and practical nature of the miracles

131 For Becket, see Frank Barlow, Thomas Becket (London, 2000), 266-8. The association between hair shirts, hermits and friars is discussed in Vauchez, Sainthood, 190-207.

132 Neither the petition of 1418 nor the Aberdeen Breviary specifically mention the repudiation of wealth but this is implied by Duthac's noble birth and later asceticism.

133 Vauchez, Sainthood, 190-214.

134 Vauchez and Swanson have identified the holy bishop as the most common sainttype in the later medieval British isles and Scandinavia (Vauchez, Sainthood, 167-72; Swanson, Religion and Devotion, 148).

135 Thomas Cranstoun and William Scherer (Table 1, nos 1, 7) had served as provost and it is clear that Robert Scot (no. 2) was also a prominent figure in local society. For Cranstoun, see J.D. Marwick (ed.), Extracts from the Records of the Burgh of Edinburgh, A.D. 1403-1528, 5 vols, Scottish Burgh Rec. Soc. (Edinburgh, 1869-92), i. 1, 9, 40. For Scherer, see St Nich. Cart., i. 17-18; John Stuart (ed.), Extracts from the Council Register of the Burgh of Aberdeen, 2 vols, Spalding Club (Aberdeen, 1844-48), 397-8 and 389-90. Several magistrates and other senior figures are included in Scot's foundation charter (Arbroath Reg., ii. 438-42).

136 I am grateful to one of the anonymous reviewers of this article for this suggestion. For the cult of Henry VI, see J.W. McKenna, 'Piety and propaganda: the cult of Henry VI', in Beryl Rowland (ed.), Chaucer and Middle English Studies (London, 1974), 72-88; L.A. Craig, 'Royalty, virtue and adversity: the cult of Henry VI', Albion 35 (2003) 187-209.

137 M.R. James (ed.), Henry the Sixth: A reprint of James Blacman's memoir (Cambridge, 1919), 14, 35.

138 Various friaries received gifts from James as he travelled to and from Tain. For the king's in the friars, see Macdougall, James $I V, 216-7$ and for a general discussion 
said to have been performed by Duthac, in particular those relating to scarcity of food and fuel, might also explain his popularity with the wider Scottish populace.

In addition to these general traits there are hints that the Duthac cult had other, more specific, intercessory functions. The shirt relic was believed to protect its wearer from harm and according to a legend related by Maior, Hugh, earl of Ross, had worn it to the battle of Halidon Hill in 1333. ${ }^{139}$ The relic failed spectacularly: Hugh was killed and, although the shirt later appeared in the royal collection, perhaps unsurprisingly there is no evidence that James IV wore it on his military campaigns. ${ }^{140}$ The king did, however, make a specific pilgrimage to Tain in August 1513, in one of his last acts before the invasion of England. ${ }^{141}$ In similar circumstances in 1482, shortly before summoning the host to face an English invasion, James III founded a chaplainry at the altar of St Duthac in Tain. ${ }^{142}$ James IV and his father may have been seeking a prophecy of military victory from Duthac, a power first recorded by David Chambers in 1631. According to Chambers, Duthac had predicted the Scottish victory at Largs in $1263 .{ }^{143}$ The invocation of saints before battle was, of course, a widespread phenomenon in the middle ages. ${ }^{144}$ Columba had been the primary military patron of early monarchs though by the time of the 1513 campaign the new royal navy was flying banners depicting SS. Andrew and Margaret. ${ }^{145}$ Andrew was also noted by an English observer at Flodden as a patron of the Scottish army - but he worked alongside Duthac and Ninian too. This suggests that the Scottish forces may have been carrying images or relics of these saints in the field. ${ }^{146}$ While Duthac's ability to prophesize victory appears in a late, uncorroborated source, Duthac seems to have had an earlier military function.

One of the most intriguing descriptions of the saint is the reference in the early sixteenth-century English poem to 'Doffin their demi-God of Ross'. ${ }^{147}$ A similar theme is apparent in the chronicle of another English observer, Ralph Hollinshead, who considered that Duthac's

138 (Continued) of James IV's piety see H.S Brown, 'Lay Piety in Later Medieval Lothian, c. 1306-c. 1513', unpublished PhD thesis (University of Edinburgh, 2006), 152-7.

${ }^{139}$ Chron. Maior, 273.

$140 T A$, iv. 354 .

141 The king was given expenses of $£ 66$ on 8 Aug. and seemingly travelled with a small retinue (TA, iv. 419, 436). The army mustered and invaded England some time between 22 and 24 Aug. (Macdougall, James IV, 272-4). This was the king's only recorded to Tain in August. Typically he visited in Mar., Oct. or May. See above, n. 111.

${ }^{142} R M S$, ii. no. 1513. This connection is made in Macdougall, James III, 195.

143 Chambers, De Scotorum, 112-3. For another Duthac prophecy, see Chron Bower, iii. 345 .

${ }^{144}$ See, for example, J.R.E. Bliese, 'Saint Cuthbert and war', Journal of Medieval History 24 (1998) 215-43.

145 TA, iv. 297, 477, 521.

${ }^{146}$ Weber (ed.), Battle of Flodden Field, 27.

147 Weber (ed.), Battle of Flodden Field, 27. 
relics were held 'in greater estimation among the superstitious sort than the holy gospel of God and merits of his son'. ${ }^{148}$ Whilst Hollinshead, writing $1578 \times 82$, was clearly influenced by protestant rhetoric, the popularity of the saint and shrine, especially in the north, is a common theme in references to the cult. ${ }^{149}$ Yet while the cult is relatively easy to trace once it had spread south, there are only hints of Duthac's popularity within these northern communities. A casual reference to 'Dubthach, a saint of holy power', in the sixteenth-century Book of the Dean of Lismore suggests Duthac enjoyed a prominent standing in Gaelic society. ${ }^{150}$ The presence of the cult in the Gaelic west is further indicated by the marking of Duthac's feast in two liturgical documents from late medieval Argyll, the Murthly Hours (which only featured one other Scottish saint) and the Glenorchy Psalter. ${ }^{151}$ According to the Martyrology of Aberdeen, the 'Hybernie' constituted a considerable proportion of the pilgrimage traffic to Tain in the early sixteenth century. ${ }^{152}$ This group of devotees remain something of a mystery. The two English writers were clearly uncomfortable with aspects of this popular cult, as perhaps were Haldenstone and Bower, who were keen to bring the saint into the political and cultural mainstream. The canonisation process launched in 1418 and the commissioning of a new vita may have been a part of this process.

Promotion and management were also key factors in encouraging, and sustaining, interest in a saint and his shrine. ${ }^{153}$ There is clear evidence of cult promotion at Tain beginning with the unknown event that appears to have taken place in the mid-thirteenth century. Although the shrine existed by 1306 it may have been another century or so before it became the subject of regular and long

148 Hollinshead included a translation of Boece's work in his chronicle and added comment, such as that quoted (Ralph Hollinshead, The Scottish Chronicle, 2 vols (Arbroath, 1805), i. 8).

${ }^{149}$ Haldenstone mentioned the popularity of the cult (Baxter (ed.), Copiale, 5). Boece noted that the saint was 'haldin amang be pepill in grete veneracion' (Chron. Boece, ii. 229) and Leslie too remarked upon his popularity among 'commune people' (Cody and Murison (eds), Historie, i. 43, 355).

150 The reference is included in a poem by Finlay the Red Bard, a poet from Highland Perthshire, who refers to the saint's vengeance on those that transgressed his sanctuary (W.J. Watson (ed.), Scottish Verse from the Book of the Dean of Lismore (Edinburgh, 1937), 137.

${ }^{151}$ Boniface of Rosemarkie is the only other Scottish saint mentioned in John Higgitt, The Murthly Hours: Devotion, liturgy and luxury in Paris, England and the Gaelic west (London, 2000), appendix 3, 27. For the Glenorchy Psalter, see London, British Library [BL], Egerton MS 2899, fo. 2.

152 This somewhat ambiguous term was used in contrast to other pilgrims described as 'Britannie'. (Forbes (ed.), Kalenders, 129). The presence of Murdchadh, son of Duthac, the late parson of Howmore on South Uist, hints at interest in the cult in the Western Isles (James Kirk, R.J. Tanner and A.I. Dunlop (eds), Calendar of Scottish Supplications to Rome, 1447-71 (Edinburgh, 1997), no. 1402.

${ }^{153}$ S.J. Ridyard, The Royal Saints of Anglo-Saxon England: A study of West Saxon and East Anglian cults (Cambridge, 1988), 5; Duffy, Stripping of the Altars, 164-5; Stephen Wilson, Saints and their Cults: Studies in religious sociology, folklore and history (Cambridge, 1982), $26-8$. 
distance pilgrimage traffic. This growing popularity was recognised by Haldenstone in 1418 and the new reliquary church was finished by $1457 .{ }^{154}$ By 1478 the shrine had come to the attention of the English traveller William of Worcester, who described Duthac as 'the saint reckoned to be the most venerated in the land of Ross'. ${ }^{155}$ Although small in scale, a sophisticated pilgrimage network had been developed in the town by the time of James IV's visits. ${ }^{156}$ In addition to the relics housed in the new church, pilgrims would have visited a ruined chapel on the links, its resident hermit and a second ruined chapel, which may have been the victim of the fire in $1427 .{ }^{157}$ Inside the main church a rood screen, flanked by two altars, separated the crowds from the high altar on which the main relics would have been displayed. ${ }^{158}$ The shrine custodians had created a complex multifocal system which presented several opportunities for pilgrims both to engage with the saint and, perhaps just as importantly, to make offerings. The organisation of the northern shrine resembled the layout of St Andrews, after Haldenstone's renovations in the 1420s, although the arrangement was fairly common and could be seen at Durham and other English shrines. ${ }^{159}$ Hints of active promotion outside the cult centre can also be seen in references to a pardoner, perhaps following the royal court, who displayed Duthac's coup in Stirling in 1508 and in Edinburgh in $1511 . .^{160}$

Responsibility for management of the shrine and the construction of the new church is difficult to identify. In contrast to other prominent shrines there is little evidence of episcopal interest in the cult. ${ }^{161}$ The first bishop of Ross mentioned in connection with the shrine was Thomas Hay (1483-92), who was involved in the establishment of Tain as a collegiate church in 1487. ${ }^{162}$ The bishop and his successors did not appear, however, to have played an active role in later royal pilgrimages.

154 Baxter (ed.), Copiale, 5. The church was completed by 1458 (ER, vi. 465).

155 J.H. Harvey (ed.), Itineraries of William Worcestre (Oxford, 1969), 7. The only other Scottish shrine to feature in his account was Whithorn.

156 Fawcett has described the 'particularly expansive architectural provisions' made for the Duthac cult in Tain (Fawcett, 'Architectural framework'), 74. For the similarities of the Tain arrangement to other reliquary shrines, see Diana Webb, Pilgrimage in Medieval England (London, 2000), 78-9.

157 The first chapel was described in 1504 as the chapel 'quair [Duthac] was born' (TA, ii. 265). James IV made gifts to the hermit at this chapel on at least one occasion (TA, ii. 125). The church which had been burnt in 1427 was described in 1504 as 'sanct Duthios chapel in the Kirk yard of Tayn' (TA, ii. 125).

158 For the screen, see I.C. Hannah, 'Screens and lofts in Scottish churches', PSAS 70 (1935-6) 181-201, at 192-3.

159 David McRoberts, 'The glorious house of St Andrews', in idem (ed.), The Medieval Church of St Andrews (Glasgow, 1976), 63-120; for the pilgrim experience at St Andrews, see ibid., 66-79.

${ }^{160}$ It is not certain if this was an independent initiative by the pardoner or part of an institutional promotion (TA, iv. 43, 180).

161 In Glasgow, Dunkeld and St Andrews successive bishops and archbishops in the fifteenth century promoted diocesan saints (Turpie, 'Scottish Saints', 179-99).

162 Durkan, 'Sanctuary', 152-4. 
They had their own diocesan saint, Boniface of Rosemarkie (depicted on their episcopal seals), to promote. ${ }^{163}$ The wider cathedral and local clergy of Ross were also conspicuous by their absence in promotion of Duthac's cult. Elsewhere local clergy played a prominent role in promoting saints in the fifteenth and early sixteenth centuries. ${ }^{164}$ In Tain the vicar, a prebendary of the cathedral chapter of Rosemarkie, is first mentioned in conjunction with the shrine in 1457 . He played a central role in activity at the shrine towards the end of the fifteenth century, appearing regularly during royal visits. ${ }^{165}$ It is possible that the white canons of the neighbouring abbey of Fearn, who had a close relationship with the town, also exercised influence on the shrine. ${ }^{166}$ The link between their mother house at Whithorn and Tain is, however, tenuous, and rests only upon gifts given by James IV to pilgrims from Tain who were visiting Whithorn in $1504 .^{167}$

Secular influences in Tain included men of the sort who witnessed the inquest of 1439 and the town's baillie. ${ }^{168}$ But although it is clear that external authorities, such as the MacDonald and Stewart earls of Ross, were interested in the cult, there is no evidence that they actively managed or promoted the shrine. The local tradition that Euphemia, countess of Ross (d. $1394 \times 98$ ), was involved in construction of the church is unsupported. ${ }^{169}$ The absence of an external, aristocratic guiding hand perhaps reflected the complex politics of the earldom of Ross. ${ }^{170}$ Conflict between the Leslies, Stewarts and MacDonalds, each of whose main territorial interest was at some distance from Easter Ross, meant that external engagement with the management of shrine and town was perfunctory during the formative period of the cult's development. ${ }^{171}$ Still, the shrine was an important economic resource and the town and its hinterland benefited financially during

163 Stevenson and Wood (eds), Scottish Seals, i. 160-3.

164 Most notably the cathedral clergy of Dunkeld, who were responsible for all extant dedications to St Columba in eastern and Lowland Scotland in the later middle ages and for the adornment of their cathedral with images of the saint (Turpie, 'Scottish Saints', 185-90).

165 Although the vicar is mentioned in 1226 his involvement in the canonisation petition of 1418 and the inquest of 1439 is not recorded (Durkan, 'Sanctuary', 149-51). However, it was at his house that William Crichton stayed in 1483-4, when fleeing from James III and various vicars played a role in later royal visits (APS, ii. 159).

${ }^{166}$ Fearn's records were destroyed in the fire of 1427. The canons held land in the burgh and the abbot witnessed the royal charter of 1487 (Adam (ed.), Calendar of Fearn, 24-6; RMS, ii. no. 1513).

167 TA, ii. 445. The possibility of a connection between Whithorn and Tain is mentioned in Daphne Brooke, Wild Men and Holy Places: St Ninian, Whithorn and the medieval realm of Galloway (Edinburgh, 1994), 179-82.

168 The MacCullochs of Plaid held the position of baillie from 1439 (Munro and Munro (eds), Acts, 39).

169 Slade, Collegiate Kirk, 10.

170 Macdougall, 'Achilles' heel?', 248-75.

${ }^{171}$ Although there is little evidence to connect the Leslies and Albany Stewarts to Tain, the MacDonald earls took a somewhat closer interest, appointing a new town baillie and presiding over the inquest of 1439 (Munro and Munro (eds), Acts, 43-5). 
royal visits. ${ }^{172}$ In the absence of external authority, it would seem likely that responsibility for the organisation of the shrine and the services required for its operation fell primarily upon local clergy, townsmen and lesser nobles.

Duthac is the most enigmatic of late medieval Scottish saints. Little can be stated with confidence about the origins of his cult and three hundred years may have passed between the historical Duthac, if he existed, and the diffusion of his cult on a national scale. The task of identifying the origins of the saint and his cult is made more complex by the subsequent attempts of various groups to appropriate an established cult. Although we are dealing with a saint ostensibly located in the central middle ages, it would seem from the petition of 1418 and from the Aberdeen Breviary that Duthac's image was developed no earlier than the later thirteenth century and that it reached its greatest popularity only in the fifteenth century. ${ }^{173}$ The revival and promotion of cults of reputedly ancient origin was not unusual. In Wales and Cornwall new saints were also at a premium, with the vacuum filled by revived or recycled cults. ${ }^{174}$ In this saintly category we can also include Fillan and Monan, 'revived' in the fourteenth century, Triduana and Palladius, 'rediscovered' at the end of the fifteenth century, and perhaps Ninian, who was reinvented in the twelfth century. Alongside new international cults, these saints filled the vacuum in the saintly landscape of late medieval Scotland. ${ }^{175}$

The Duthac cult was, however, a fundamentally different beast from other reinvented saints. Firstly it lacked an obvious royal, magnate or episcopal patron and identifiable institutional support. ${ }^{176}$ Although James IV and James $\mathrm{V}$ were major patrons, royal support seems to have been a reaction to Duthac's identity as a significant and popular

172 A typical visit by James IV in 1504 involved four separate offerings of $14 s$ to the town's churches and relics, further offerings to the priests and to the provost Donald Reid, a payment to the man who bore Duthac's bell and payment for entertainment by Ross of Balnagown's harper (TA, ii. 256, 353, 462).

173 For typical miracle types in this period, see Michael Goodich, Miracles and Wonders: The development of the concept of miracle, 1150-1350 (Aldershot, 2007), 4-6.

174 L.M. Garland, 'Aspects of Welsh Saints' Cults and Pilgrimage, c. 1066-1530', unpublished PhD Thesis (King's College, University of London, 2005), 68, 90; Nicholas Orme, The Saints of Cornwall (Oxford, 2000), 22, 37. The cults of AngloSaxon saints, such as Cuthbert and William, were revived in the diocese of York during the later middle ages (Jonathan Hughes, Pastors and Visionaries: Religion and Secular Life in Late Medieval Yorkshire (Woodbridge, 1998), 299, 315-17.

175 Taylor, 'Fillan', 175-211; Michael Penman, 'Christian days and knights: the religious devotions and court of David II of Scotland 1329-71', Historical Research 71 (2002) 249-72; Brown, 'Triduana', 45-69; Higgitt, 'From Bede', 187; T.O. Clancy, 'The real St Ninian', IR 52 (2001) 1-29.

176 Royal, magnatial or episcopal patrons are evident in the development of the cults of Fillan (Robert I), Monan (David II, 1329-71), Triduana (James III) and Palladius (William Scheves, archbishop of St Andrews, 1476-97) and perhaps Munnu (R. Butter, 'St Munnu in Ireland and Scotland: an exploration of his cult', in Boardman and Williamson (eds), Cult of Saints, 21-42). Ninian was the patron saint of the bishops of Galloway and promoted by the Premonstratensian canons at Whithorn (Higgitt, 'From Bede', 1-29). 
local figure in the north, rather than a stimulant for the expansion of the cult. Secondly, there is no clear pivotal point, or what might be termed 'Fillan moment', for Duthac that would explain the mutation from a localised to national cult. ${ }^{177}$ The possible translation of the midthirteenth century or the capture of Bruce's family at the shrine in 1306 were too early while royal pilgrimages in the 1490s occurred too late to explain plausibly the cult's expansion in the fifteenth century. There is also little evidence that devotion to the saint was shaped by patriotic sentiments. Duthac was neither one of the missionary saints considered by contemporary chroniclers to have contributed to spread of christianity in Scotland; nor was he connected to the Scottish cause in the wars of independence, as Fillan was. ${ }^{178}$

Having discounted royal and clerical patronage and devotional nationalism as explanations for the success of the cult we are left with Duthac as a saint-type. Eamon Duffy has shown that the role of management and clerical encouragement in influencing devotion to particular saints can be overstated. ${ }^{179}$ 'Lay report and word of mouth' has an equally important role in the process and are readily apparent in the dissemination of Duthac's cult. ${ }^{180}$ It is clear that the saint provided a model of sanctity that appealed especially to the later medieval urban elite. This model took the form of the kind neighbour and eremitical friar saint-types which were fashionable across Europe. The influence of the mercantile devotees led to the dissemination of the cult on a national scale which, combined with the local significance of Duthac in Ross, provided the catalysts for the royal engagement with the saint and shrine in the later the fifteenth century. Whilst the characteristics attributed to the saint place him firmly within the prevailing devotional fashions of late medieval Europe, the localised management and unusual emergence of the cult make 'the demi-God of Ross' something of an interesting anomaly both in Scotland and beyond.

177 Taylor has shown that Bruce engagement with Fillan began following the battle of Dalry, close to the saint's shrine, in 1306 (Taylor, 'Fillan', 175-211). Bower and others thought that a similar pivotal moment, an arrow in the head or ship wreck, accounted for David II's interest in St Monan (Penman, 'Christian days and knights', 249-72).

178 Chron. Bower, vi. 361-3; viii. 55.

179 Duffy, Stripping of the Altars, 165.

180 Duffy, Stripping of the Altars, 168-9. 